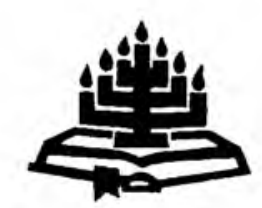

\title{
'n Waarskynlike bedieningsmilieu vir die GKSA in die dekades na 2000
}

\author{
J.M. Vorster \\ Skool vir Kerkwetenskappe \\ Potchefstroomse Universiteit vir $\mathrm{CHO}$ \\ POTCHEFSTROOM \\ E-pos: dekjmv@puknet puk.ac za
}

\begin{abstract}
A possibte context of ministy for the Reformed Churches in South Africa (GKSA) in the decades beyond 2000

This article focuses on the possible milieu for the ministry of the Reformed Churches in South Africa in the decades beyond 2000. From a churchhistorical and futurological point of view the paradigm shift from modernism to posimodernism is investigated. The effect of the paradigm shift as well as the emerging megatrends is analysed and proposals for the focus of the future ministry of these churches are formulated. These proposals are outlined within the broad framework of Biblical principles for the ministry of the church.
\end{abstract}

\section{Inleiding}

Met die wisseling van die twintigste eeu voor hande kyk ekklesioloë tans weer aandagtig na die rol en betekenis van die kerk binne die groter perspektief van die toekoms van die Christendom. Hierdie hernude belangstelling word gestimuleer deur die diepgaande veranderingsproses waaraan die Westerse samelewing onderhewig is. Hierdie veranderingsproses word op insiggewende wyse bespreek deur Toffler in sy bekende werke wat hy sedert 1970 geskryf het (vgl Toffler, 1971:276; 1980:23 en 1990:1). In sy 1980-publikasie het Toffler die veranderingsproses treffend omskryf toe hy gesê het:

A new civilization is emerging in our lives, and blind men everywhere is trying to suppress it. This new civilization brings with it new family styles; changing ways of working, loving and living; a new economy; new political conflicts; and beyond all this an altered consciousness as well. Pieces of this new civilization exist today. Millions are already attuning their lives to the rhythms of tomorrow. Others terrified of the future, are engaged in a 
desperate, futile flight into the past and are trying to restore the dying world that gave them birth. The dawn of this new civilization is the single most explosive fact of our livetimes (Toffler, 1980:23).

Wat Toffler in 1980 gesê het, het sedertdien al hoe meer sigbaar geword. Die veranderinge raak die kerk intens. Oor die invloed van die veranderinge op die kerk wêreldwyd het, onder andere Anderson (1990:21), Wuthnow (1993:19), Mead (1993:8) en Woods (1996:8) deeglike navorsing gedoen. Die effek van die veranderingsproses vir die kerke in Suid-Afrika word uiteengesit in die werke van Pieterse (1992a:16 en 1992b:325); Hendriks (1996:138) en Vorster (1996: 14). Uit bogenoemde navorsing is dit baie duidelik dat die veranderingsproses in die wêreld, soos dit hom ook in Suid-Afrika vergestalt, bepaalde nuwe eise aan die kerk stel. Soos telkens in die kerkgeskiedenis die geval was, kom sekere probleemgebiede tans meer in die fokus as ander en beïnvloed hierdie realiteit die gerigtheid van die kerk (Woods, 1996:6). Die rolvervulling van die kerk word immers, benewens sy prinsipiële fundering, ook gerig deur die konteks waarin dit funksioneer. Hierdie feit word duidelik aangetoon deur Walker (1992: 695 ) in sy omvattende uiteensetting en beoordeling van die geskiedenis van die kerk.

Met hierdie realiteite moet die Gereformeerde Kerke in Suid-Afrika (GKSA) ook rekening hou. Die effek van die veranderingsproses kan nie weggedink word met die fundamentalistiese beskouing dat die kerk bo die werklikheid lewe en dat die rol van die kerk altyd op dieselfde wyse gekontekstualiseer word nie. Anderson (1990:15) is korrek wanneer hy sê: "Change is not the choice, how we handle it is".

Ten einde die spesifieke fokusgebiede vir die roeping van die GKSA in die dekades na 2000 bloot te lê, is dit nodig om die veranderingsproses te analiseer en vas te stel in watter sosio-kulturele konteks die kerk in hierdie periode inbeweeg en hoe hierdie werklikheid die rol van die kerk gaan rig.

Futurologiese verkenning is 'n nuwe dissipline in historiese en sosiologiese navorsing. In die kerkgeskiedenis geniet hierdie dissipline tans aandag (vgl. Edwards, 1987:357; Moltmann, 1994:75; Küng, 1995:792). Hierdie verkenning word gedoen vanuit die waarneembare tendense in die kontemporêre geskiedenis, met ander woorde, die toekomstige scenario op die mediumtermyn kan met redelike akkuraatheid bepaal word op grond van huidige tendense in die samelewing. Die doel van hierdie navorsing is om 'n waarskynlike bedieningsmilieu vir die GKSA in die dekades na 2000 te identifiseer en aan te toon watter fokusareas in dié periode die gerigtheid van die kerke in hulle rolvervulling gaan bepaal. Die sentraalteoretiese argument van die navorsing is dat huidige tendense in die samelewing 'n geloofwaardige aanduiding gee van die milieu van die volgende dekades en dat spesifieke fokuspunte vir die rol van die kerk daaruit geformuleer kan word. 
Om dié doel te bereik word agtereenvolgens aandag gegee aan die begrip paradigma in kerkhistoriese perspektief, die effek van 'n paradigmaverskuiwing, en ontluikende megatendense met die spesifieke fokuspunte vir die GKSA.

\section{2. 'n Paradigma in kerkhistoriese perspektief}

Sedert Kuhn (1970:viii) die term "paradigma" in wetenskaplike navorsing aan die orde gestel het, is die begrip gepopulariseer deur Barker (Woods, 1996:10). Daarna is die begrip met verskillende betekenisnuanses ook in die teologie toegepas. Kuhn (1970:viii) het 'n paradigma gedefinieer as "universally recognised scientific achievements that for a time provide model problems and solutions to a community of practitioners".

Paradigma impliseer dus 'n werklikheidsbeskouing wat in die eerste plek navorsers se uitgangspunte en benadering tot die veld van ondersoek bepaal. Die beskouing kan bewustelik of onbewustelik bestaan en gaan die reëls en teorie van wetenskaplike ondersoek vooraf (Kuhn, 1970:44, 46).

In die teologie het die beskouing van Kuhn byvoorbeeld inslag gevind in die Hermeneutiek as 'n beskrywing van die uitgangspunte wat die teorie van Skrifverstaan voorafgaan (bv. Lategan, 1988:65, Adam; 1995:11). So word die histories-kritiese metode van Skrifverstaan beskrywe as 'n paradigma (Vorster, 1988:33). Sanks (1974:129) pas Kuhn se teorie toe op die Rooms-Katolieke beskouing oor die gesag van die kerk, terwyl Bosch (1991:186) Kuhn en Küng se teorieë met vrug in die Missiologie en veral as 'n maatstaf vir die onderskeiding van historiese missiologiese modelle aanwend. In die Ekklesiologie het Dulles (1987:29) die teorie toegepas as sleutel tot die verstaan van verskillende tradisionele kerkmodelle. In teenswoordige kerkhistoriese navorsing het Küng (1995:61) die begrip in sy periodisering van die kerkgeskiedenis aan die orde gestel (vgl. ook Vorster, 1998:208).

Ten spyte van die verskillende definiërings en toepassings van die begrip paradigma is daar sekere prinsipes vir die verstaan van die begrip wat Kuhn en sy volgelinge aantoon. Dit is die beskouing dat wetenskaplike navorsing altyd bepaal word deur 'n lewens- en wêreldbeskouing wat sekere beginsels as voorveronderstelling in die navorsingsproses daarstel. Die navorser, ook die teoloog, benader sy veld van ondersoek nie neutraal, onbelas of objektief nie Met hierdie beskouing het Kuhn gebreek met die positiwisme. Op dié wyse, soos deur Kuhn gedefinieer, kan die begrip paradigma ook in die Ekklesiologie aangewend word. 'n Paradigma in hierdie verband omskryf die ekklesiologiese uitgangspunte en verwagtings wat die kerkbeskouing en bedieningspatrone van ' $n$ bepaalde historiese tydvak bepaal en die funksionering van die kerk in die bepaalde periode beheers. 
Om die bedieningsmilieu van 'n bepaalde tydvak te definieer, moet die historiese paradigma van daardie tydvak ontleed word. Daar moet dus vasgestel word watter lewens- en wêreldbeskouing en filosofiese vertrekpunte daardie periode gekarakteriseer het. Om die toekomstige bedieningmilieu na waarde te skat, moet die huidige lewens- en wêreldbeskouing geanaliseer word. Gesaghebbende navorsers is dit egter eens dat die huidige periode gekenmerk word deur 'n paradigmaverskuiwing (vgl. Küng, 1995:773). So 'n verskuiwing het 'n dinamiese en diep ingrypende invloed op 'n gemeenskap en dus ook op die kerk. Om enigsins ' $n$ analise van die toekomstige bedieningsmilieu te waag moet die konsep van 'n paradigmaverskuiwing en die prinsipiële begrensing daarvan vanuit die perspektief van die Gereformeerde ekklesiologie eers aan die orde gestel word.

\section{Die huidige paradigmaverskuiwing}

\subsection{Die konsep "paradigmaverskuiwing"}

Volgens Kuhn (1970:111) vind paradigmaverskuiwings plaas wanneer die ou paradigma nie meer antwoorde bied op nuwe realiteite nie. Dan begin die navorser nuwe terreine ontgin en vind hy nuwe sleutels as instrumente om 'n nuwe werklikheid te ontgin. So vind daar 'n rewolusie plaas in sy teorieë, navorsing en uiteindelike resultate. Dieselfde proses voltrek hom in die teologie maar tog met 'n belangrike verskil. Waar die paradigmaverskuiwing in die natuurwetenskappe 'n totale oorgang van 'n oue na 'n nuwe aandui, beteken dit in die teologie dat die nuwe nie die oue dadelik vervang nie, maar dat hulle langs mekaar kan voortbestaan (Bosch, 1991:186). Verskeie paradigmas in dieselfde veld van ondersoek kan vir 'n tyd langs mekaar bestaan, maar die een wat die beste antwoord bied op nuwe realiteite sal ontwikkel tot die dominante. Dieselfde kan gesê word oor die paradigmas in die kerkgeskiedenis. 'n Nuwe paradigma vervang nie die ou paradigma nie, maar veroorsaak drastiese veranderinge in die denk- en leefwêreld. Die ou paradigma kan nog voortbestaan maar dan nie meer as die dominante nie omdat dit nie meer ' $n$ antwoord bied op die nuwe realiteite nie. Sy invloed vervaag omdat dit nie die nuwe eise betrek nie. Wanneer die kerk hom rig op die ou paradigma word dit dus irrelevant.

\subsection{Makro-, meso- en mikroparadigmaverskuiwings}

Paradigmaverskuiwings kan plaasvind op die makro-, meso- en mikrovlak. 'n Paradigma op makrovlak bepaal die totaliteit van lewe en denke in 'n omvangryke en universele hoofperiode in die geskiedenis. 'n Paradigma op mesovlak sal 'n onderliggende deel van 'n hoofperiode in die geskiedenis bepaal terwyl die paradigma op mikrovlak weer 'n onderdeel van die mesovlak bepaal. Die paradigma op makrovlak raak dus nie 'n denkrigting of 'n bepaalde filosofiese skool nie, maar 'n wyse van denke. Die mesoparadigma raak denkrigtings wat groei uit die wyse van denke van die makroparadigma. Die paradigmas op 
mikrovlak raak weer tradisies wat binne 'n bepaalde denkrigting op die mesovlak bestaan. Verskuiwings op mikrovlak vind dus meer gereeld en selfs deurlopend plaas; op mesovlak minder deurlopend maar meer ingrypend. Verskuiwings op makrovlak is alles omvattend en verander die denk- en leefwêreld van mense in totaliteit. In historiese navorsing moet dus vasgestel word op watter vlak die verskuiwing plaasvind en hoe dit die kerk raak.

Vandag word vanuit verskeie geesteswetenskaplike dissiplines aanvaar dat daar tans 'n paradigmaverskuiwing op die makrovlak plaasvind (lees in hierdie opsig Mead, 1993:43, Wuthnow, 1993:148, Beckham, 1995:21 en Vorster, 1996:80). Lambeth (1997:205) vat hierdie beskouing goed saam wanneer hy sê:

In the years since the uprisings of the late 1960s swept the cultures of Europe and America, the emergence of a radical new critique of modernity and the heralding of a corresponding transition into postmodemity have increasingly occupied the minds of many cultural critics, philosophers and theologians alike.

Vanweë die diep ingrypende en universele invloed van die verskuiwing en die betekenis daarvan vir die kerk moet die aard van die huidige makroparadigmaverskuiwing nader ontleed word.

\subsection{Die aard van die makroparadigmaverskuiwing}

Barker (1996:xv) verdeel die geskiedenis van die Westerse beskawing in drie tydperke. As indelingsprinsipe gebruik hy verskillende dominante grondmotiewe wat die denk- en leefwêreld van mense vir 'n tydperk bepaal het. Hierdie tydperke kan beskou word as makroparadigmas. Hy tipeer die tydperke as premoderniteit, moderniteit en postmoderniteit. In elke periode was daar 'n unieke dominante grondmotief wat kultuur, godsdiens, politiek en filosofie gedomineer het.

Die dominante grondmotief in die premoderne paradigma was die idee dat alles beheer word deur die metafisiese. Die rede was gedomineer deur die religie (Heelas, 1993:109). Peperzak (1997:321) defmieer dié periode as die tyd van "unscientific premodernity". Die dominansie van die metafisiese het gelei tot 'n kultuur waarin aanvaar is dat alles deur metafisiese kragte beheers is. Godsdiens as sodanig is hoog geag (Smith, 1993:157). Hierdie idee het 'n bepaalde lewenswyse tot gevolg gehad. In die lewe het dit gegaan om die basiese dinge soos kos, bestaan en voortbestaan. Die mens- en kultuurbeskouing was pessimisties en alles is gedoen onder leiding van die geloof in die beheer van metafisiese kragte (Polak, 1958:23; Euben, 1997:430). Die ontwikkeling van wetenskap en tegnologie het agterweë gebly (Ozment, 1995:55). In die Christelike gemeenskappe het die kerk 'n leidinggewende rol gespeel en is die geloof nooit bevraagteken nie. Hierdie premoderniteit was die oorsaak van die kerksentriese 
samelewing van die eerste dertien eeue na Christus en die onaanvegbare gesagsposisie van die Pous en die klerus.

Met die Renaissance het 'n makroparadigmaverskuiwing begin intree toe die dominansie van die metafisiese stelselmatig bevraagteken is. Dié proses het uitgemond in die Verligting toe die rede die grondmotief vir die menslike lewe geword het (Boas, 1957:458). Die rede van die mens het die metafisiese vervang as dominante faktor in die bestaan van die mens (vgl. Cairns, 1982:444; McGrath, 1992:132). Die modernisme het gelei tot 'n optimistiese siening van die vermoë van die mens en sy rede. Die mens is gesien as die bepaler van sy eie bestemming. Op grond van hierdie beskouing het 'n nuwe waardesisteem ontwikkel waarin die klem geplaas is op die belange en die regte van die mens self.

Groot politie! en sosiale strukture het ontwikkel asook ekonomiese stelsels waarin die viuesre feudalisme met sy klasseverskille verwerp is. Wetenskap en tegnologie het opgebloei. Die nuwe mensgerigtheid het die fokus algaande weggeskuif van godsdiens en die mag van die kerk en tradisionele teologiese beskouings is of verwerp of met 'n nuwe inhoud gevul (vgl. die deeglike uiteensetting van Banning, 1961:266). Die moderniteit van die laat-negentiende eeu en vroeg-twintigste eeu het gelei tot Skrifkritiek en ongekende sekularisme. Skrif en kerk het die sestiger- en sewentigerjare van die twintigste eeu, onder die aanslag van die menslike rede, aan 'n ingrypende herinterpretasie en rewolusionêre herdefiniëringsprogram onderwerp. Hiervan is die destydse opspraakwekkende sekularisasieteologie van Robinson (1964), Hamilton (1966), Cox (1966 en 1967) Altizer (1966), Sölle (s.j., 1965, 1970 en 1972), Sölle en Steffensky (1969) en Van Buren (1968) duidelike voorbeelde.

Die bevrydingstryd van die sestigerjare het, soos reeds gesê, 'n derde makroparadigmaverskuiwing in die bekende geskiedenis van die mensdom ingelui. Stelselmatig word die moderniteit met sy klem op die dominansie van die rede vervang deur 'n nuwe lewens- en wêreldbeskouing en siening van die gemeenskap, kultuur, godsdiens en wetenskap. Die nuwe orde word in algemene terme postmoderniteit genoem. Volgens Küng (1995:771) is die term eerste gebruik deur die Franse filosowe Lyotard en Welsch. 'n Wye verskeidenheid definisies van postmoderniteit het sedertdien vanuit verskillende wetenskappe die lig gesien.

Oor die algemeen word aanvaar dat die postmodemiteit hom verset teen die mag van die rede, wetenskap en tegnologie en die groot super-sosiale strukture wat dit tot gevolg het. Die eg menslike soos ervaring, menslikheid, verskeidenheid en die relatiwiteit van waarheid word op die voorgrond gestel. Absoluuthede en absolutistiese stelsels word verwerp. In 'n onlangse publikasie sê Herholdt (1998:216, 218): "Postmodernism is an effort to restore the value of human feelings as part of experience" en: "Postmodernism aspires to provide an 
alternative approach to reality in such a way that it could yield a significantly new and improved way of understanding the world".

Postmoderniteit het twee uitstaande kenmerke

- Die fokus op die mens en sy voorveronderstellings

Die fokus in postmoderniteit is nie op die objek vanuit die sogenaamde objektiewe rede soos in die wetenskapsbeskouing van die moderniteit nie, maar op die subjek, die mens self met sy voorveronderstellings, gevoel, geloof en spiritualiteit. Dié denkwyse erken die deurslaggewende rol van voorveronderstellings in die denke van die mens. Alle wetenskaplike resultate en die mens se ondersoek van dinge word wesenlik bepaal deur sy voorverondestellings. Die gevolg daarvan is dat objektiewe waarhede en etiese reëls volgens dié denkwyse nie moontlik is nie. Absolutisme, gebaseer op 'n redelik uitgewerkte en verklaarde beginsel van wat reg en verkeerd is, vervaag. Soos wat die moderniteit godsdiens bevraagteken het, bevraagteken postmoderniteit die rede (Adam, 1995:11). Daarom aanvaar postmoderniteit die geldigheid van meer as een moontlike waarheid oor dieselfde aangeleentheid. Reg en verkeerd word vervang met geldig en óók geldig. Alle vorme van fundamentalisme waarin een stel etiese reëls as die basis van die lewe van die mens gestel word, word verwerp. Die slagkrete van die beweging is "nothing is sacred" en "everything goes".

\section{- Die nuwe belangstelling in die metafisiese}

Die tweede uitstaande kenmerk van die postmoderniteit is die nuwe belangstelling in die metafisiese. Die individu se lewe in verhouding met en binne die geheel van die kosmos kom onder die soeklig. Die bestaan van God en die mens se inherente godsdienssin word erken. Hierin word totaal wegbeweeg van die sekularisme van die moderniteit. Waar die vraag in die moderniteit was na die bestaan van God, fokus die postmoderniteit op die vraag: Hoe tree 'n mens in in 'n verhouding met God? Spiritualiteit en godsdiens het weer belangrik geword omdat dit erken word as die diepste essensie van menswees.

In die premoderniteit het die geloof in die afhanklikheid van die metafisiese die lewe van mense beheer. In die moderniteit gaan dit om die dominansie van die menslike rede met sy gevolglike wetenskap, tegnologie en makro-sosiale stelsels. Die postmoderniteit daarenteen wil uitgaan van die dominansie van menslike ervaring. Die einde van die twintigste eeu word dus gekenmerk deur die makroparadigmaverskuiwing van moderniteit na postmoderniteit met al die verwarring, onsekerheid en konflik wat met so 'n makroparadigmaverskuiwing op makrovlak gepaard gaan. Nie net denkrigtings nie, maar denkwyses verander en daarom is alles aan fundamentele verandering onderworpe. Hierdie verskuiwing het, soos dit was met die verskuiwing van premoderniteit na moderniteit, ingrypende implikasies vir die bedieningskonteks van die kerk. 
Hierby moet in gedagte gehou word dat die kerk en die konteks waarin hy beweeg onvermydelik op mekaar betrekking het. Daarom moet aandag gegee word aan die effek van die huidige makroparadigmaverskuiwing vir die kerk.

\subsection{Die effek van die makoparadigmaverskuiwing}

Die onmiddellike effek van die paradigmaverskuiwing op die kerk vandag, kan in drie aspekte saamgevat word. Die eerste is die verskuiwing van positiwisme na relatiwisme. Die tweede is die verskerpte spanning tussen tradisie en vernuwing en die derde is die voorkoms van gekonsentreerde konflik. Aan elkeen van hierdie aspekte word kortliks aandag gegee.

\subsubsection{Die verskuiwing van positiwisme na relatiwisme}

Die waarheidsbeskouing van die moderniteit is wesenlik bepaal deur die logiese positiwisme. Volgens hierdie beskouing is waarheid objektief en kan dit alleen waarheid wees as dit logies bewys kan word (Cook, 1988:395). Die rede staan voorop en bepaal wat waarheid is. Ten opsigte van elke saak kan daar dus ook net een geldige waarheid wees. Hierdie beskouing het die denke, wetenskapsbeoefening en sosiale strukture wesenlik beïnvloed. Rasionalisme het die bestaan van voorwetenskaplike vertrekpunte en geloofsuitgangspunte ontken. Soos reeds gesê, hot hierdie filosofie die Skrif en die kerk aan hewige kritiek onderwerp. Skritk ،uek het hoogty gevier en die funksionaliteit van die kerk is bevraagteken. In die sosiale lewe het hierdie beskouing gelei tot die verabsolutering van superstrukture en ideologieë waarin die mens sy heil wou vind.

Marcuse (1968:53 en 1971:10) het in sy kultuuranalise hierdie samelewing beskryf as ' $n$ verknegtende samelewing waarin die mens as "eendimensionele mens" nie meer leef nie, maar geleef word. Hy het met sy filosofie van rewolusie gepleit vir die bevryding van die mens uit hierdie magstrukture. Hierin is hy nagevolg deur die teologie van bevryding (vgl. Shaull, 1969:190; Gutierrez, 1974:223 en Fierro, 1977:237). Verset het opgebou teen die positiwistiese lewens- en wêreldbeskouing en die verknegtende samelewing wat daaruit voortgevloei het. Omdat die moderniteit hierdie verset nie kon beantwoord nie, het die paradigmaverskuiwing plaasgevind. Superstrukture uit die era van moderne sosiale beplanning soos die Kommunisme, die Berlynse muur, staatsbeheerde ekonomieë en apartheid het in duie gestort en plek gemaak vir gedesentraliseerde demokrasieë met 'n hoẻ premie op menseregte.

Die postmoderniteit gaan, anders as die moderniteit, uit van die geldigheid van voorwetenskaplike voorveronderstellings en bevraagteken daarom die bestaan van objektiewe kennis en absolute waarheid. Omdat elke mens se benadering tot die werklikheid gekleur word deur sy voorveronderstellings, agtergrond en geloof, kan hy nie die volle waarheid ontgin nie. Hy sien vanuit sy hoek een 
kant van die volle saak. Waarheid is daarom relatief en meer as een konklusie oor 'n saak kan geldig wees.

Vir die kerk het hierdie nuwe gewilde werklikheidsbeskouing besondere implikasies. Hiervolgens word die Skrif wel gesien as 'n geldige bron van godsdienstige belewing, maar nie as uniek nie. Ander bronne word ook as geldig beskou. Verskillende hermeneutiese metodes word ook as geldig aanvaar. Kerklike leerstellinge kan van tyd tot tyd, plek tot plek en van situasie tot situasie verskil en elke mens moet sy keuse maak. Godsdienste word as gelykwaardig aanvaar en etiese beginsels as histories en kontekstueel bepaald. Geen godsdiens, filosofie of ideologie kan homself aanbied as die waarheid nie. Die skerp kritiek van die moderniteit op Skrif en kerk is vervang met aanvaarding en erkenning. Christelike spiritualiteit en gemeenskapsbelewing is weer in ere herstel, maar dan as een geldige vorm van spiritualiteit tussen vele ander. Die Christelike geloof het besliste waarde vir die mens maar word nie beskou as die enigste belewing van 'n verhouding met God nie. 'n Objektiewe waarheid en absolute beginsels het dus plek gemaak vir relatiewe waarheid en godsdienstige en etiese pluralisme. Hierdie relatiwisme is die een duidelike effek van die huidige paradigmaverskuiwing.

Vir die kerk en gereformeerde teologie bring die konteks nuwe uitdagings (vgl Tracey, 1994:104; Herholdt, 1998:218). Vir die Gereformeerde teologie wat nie uitgaan van relatiewe waarhede nie, impliseer dit dat opnuut besin moet word oor die geloofwaardige formulering en toepassing van leerstellige en etiese beginsels (vgl. in hierdie verband Gibbs, 1993:195). Hierop word later weer teruggekom.

\subsubsection{Die spanning tussen tradisie en vernuwing}

Spanning tussen tradisie en vernuwing is altyd deel van die samelewingsdinamiek. In 'n tyd van 'n makroparadigmaverskuiwing word hierdie spanning egter baie meer intens omdat raakpunte verdwyn. Hierdie spanning ontstaan as gevolg van die feit dat 'n persoon wie se denke geanker is in die verbygaande paradigma en die persoon wie se denke geanker is in die opkomende paradigma 'n totale kommunikasiebreuk beleef. Nie hulle denke nie, maar ook hulle wyse van dink verskil.

Hierdie spanning word geloofwaardig verklaar deur Zylstra (1992:11) wanneer hy dit op die kommunikasiebreuk tussen die kerk en die postmodeme mens toepas. Die bediening van die kerk is volgens hom nog geskoei op die moderne model terwyl die mens vandag al hoe meer postmodernisties dink en doen. Hy verwys na Ong se teorie van 'n "changing sensorium" waarmee die kerk te doen kry. Dit beteken dat die "ontvangstoestel" van die moderne mens en die "sendtoestel" van die kerk as gevolg van verandering nie meer op mekaar ingestel is nie. Die waardes wat die mens soek in 'n veranderende wêreld, vind hy (nog 
nie) by die kerk nie. Hierdie spanning word tans in die kerke gevoel en modaliteite binne kerke ontwikkel met skerper skeidslyne as vroeër.

\subsubsection{Gekonsentreerde konflik}

Die direkte gevolg van die spanning tussen tradisie en vernuwing skep gekonsentreerde konflik. Mense ervaar meer verandering as wat hulle psigies kan hanteer en dit lei tot konflik. Toffler (1971:20) sien hierdie konflik as die gevolg van die "future schock" wat mense beleef. Agressie, wantroue, onsekerheid en moedeloosheid neem toe. Vir baie gelowiges was die kerk nog die laaste bastion teen verandering. Verandering binne die kerk vererger die konflik vir hulle nog meer.

Die gekonsentreerde konflik raak veral die predikant intens. Hy kan óf tradisioneel of vernuwend wees in sy hantering van sy bediening. In Zylstra se terme verloor hy kommunikasie met die mense van die ander paradigma. Hierdie konflik skep in 'n groot mate vir die predikant 'n beroepskrisis en hy raak onseker in die bediening. Spanning, depressie en uitbranding neem toe onder pastoriegesinne in alle kerklike tradisies. Die konflik maak mense ook onwillig om in besondere dienste te dien en passiwiteit neem toe. Gelowiges soek 'n nuwe geestelike tuiste in kleiner informele eenhede soos selkerke of beleef hulle geloof spontaan buite die gevestigde kerke (Wuthnow, 1993:30; Klaas, 1996:51; vgl. ook Woods, 1996:37).

Bogenoemde verskynsels is. die effek van die huidige makroparadigmaverskuiwing vir die kerk vandag. Met die voortgang van die verskuiwing is daar egter nuwe megatendense wat ontluik. Om 'n oorsig te gee van die waarskynlike bedieningsmilieu vir die dekades na 2000 is dit nodig om hierdie ontluikende megatendense te analiseer.

\section{Ontluikende megatendense}

Daar kan vanuit huidige ontwikkeling gesien, vier ontluikende megatendense geidentifiseer word. Hierdie megatendense is: bevryding en menseregte; gesagsverskuiwing en demokratisering; 'n nuwe waardesisteem en die soeke na spiritualiteit.

\subsection{Bevryding en menseregte}

Soos reeds aangedui is, het die verskuiwing weg van moderniteit begin met die filosofie van bevryding wat in die sestigerjare in die Westerse wêreld posgevat het. In hierdie denkstroom het dit gegaan om die "eendimensionele mens" se bevryding van verknegtende sosiale superstrukture. Veral onder studente het die "New Left"-beweging 'n kultuur beoefen wat in alle opsigte die bestaande orde moes opponeer (vgl. hieroor Roszak, 1969:42 en Vorster, 1981:219). Hoewel die radikalisme van hierdie filosofie en die beweging wat daaruit voortgekom 
het, later afgeneem het, het dit die idee van bevryding gevestig en die prosesse ter bereiking daarvan in werking gestel.

In dié proses het die beklemtoning van menseregte groot momentum gekry. Hoewel die konsep menseregte oor die afgelope twee eeue bekend is en reeds lankal in die konstitusies van gevestigde demokrasieë beslag gekry het, is dit sedert die sestigerjare met nuwe ywer gepropageer en tot sy uiterste konsekwensies uitgewerk (vgl. Lochman, 1976:8 en Van der Vyver, 1974:30). Magstate waarin die parlement die hoogste gesag is, is met regstate vervang waarin die mag van die owerhede deur konstitusies en handveste van menseregte beperk is.

Die samelewing van die toekoms sal georden word volgens die beginsels van menseregte soos wat dit internasionaal gedefinieer word. Owerhede, kerke, ekonomiese instellings en alle ander sosiale instansies sal beoordeel word volgens hulle handhawing van menseregte. Internasionale handel en beleggings sal bepaal word deur die verskillende vennote se eerbied vir menseregte. Van opvoedingsinstellings sal verwag word om te werk aan die opbou van 'n kultuur van menseregte.

Met die konstitusie van 1996 het Suid-Afrika ook hierdie pad betree - 'n pad wat vir die kerke 'n nuwe milieu skep. Die konsep van menseregte is nie vreemd aan die gereformeerde tradisie nie (Wingren, 1978:16; GES, 1983:97; Du Toit, 1988:48, Van Wyk, 1991:253; Villa-Vicencio, 1992:137) Die formulering en die toepassing daarvan het egter vir die kerk ernstige implikasies, soos byvoorbeeld die wettiging van aborsie op aanvraag en die moontlike inmenging van die konstitusionele hof in kerklike sake. Die kerke sal in hulle profetiese taak teenoor die owerheid nougesette aandag moet gee aan die formulering en interpretering van menseregte en sal in hierdie verband ook moet optree as die waghond oor die owerheid en ander samelewingsverbande om toe te sien dat menseregte uitgewerk word in die lig van die Skrif.

'n Grondwet moet egter gedra word deur 'n algemene demokratiese ingesteldheid en 'n kultuur van menseregte onder die bevolking - anders is dit van geen waarde nie. Aan so 'n kultuur is daar in Suid-Afrika nog 'n groot gebrek (Jordaan, 1994:33). Daarom is naas die beklemtoning van die beginsel van menseregte ook die opbou van 'n kultuur van menseregte belangrik, juis omdat daar ten opsigte van etiese beginsels ' $n$ voortdurende wisselwerking is tussen Bybel en situasie (König, 1993:56). Die kerke het die verpligting om die wetlike erkenning van die regte van mense in die samelewing te beklemtoon (Kik, 1982:91; Höffe, 1982:246). Veral in die huidige tyd is die uitvoering van hierdie taak in Suid-Afrika uiters belangrik. Dit gaan in die volgende dekades van groot belang wees dat die geïnstitueerde kerk in sy profeties-kritiese roeping, en Christene, in die vervulling van hulle politieke rol, prinsipieel-etiese getuienis lewer ten gunste van die beskerming en die handhawing van menseregte. So kan 
vanuit Christelike kant bygedra word tot die vestiging van 'n positiewe gesindheid ten opsigte van 'n kultuur van demokrasie en menseregte.

\subsection{Gesagsverskuiwinge en demokratisering}

Die bevrydingsproses het ook daartoe gelei dat gesag gedesentraliseer word en dat alle instellings aan 'n demokratiseringsproses onderwerp word. Toffler (1990:10) beskryf in sy jongste beoordeling van megatendense in die huidige samelewing die proses as 'n "powershift". Gesag verskuif van 'n magsryke topstruktuur na kleiner eenhede. Groot korporasies en sentrale regerings desentraliseer. Hy wys hierdie tendens ook aan in die kerk. Die gesag van die Pous in die Rooms-Katolieke tradisie is aan die afneem en in die Protestantse tradisie gebeur dieselfde met sinodes en ekumeniese liggame. Die klem verskuif na die gesag van die plaaslike kerk en in die plaaslike kerk van die kerkraad na die gemeente. Hierdie megatendens lei na 'n verset teen institusionalisme en formalisme; die soeke na belewing in kleiner gemeenskappe en 'n beweging terug na eenvoud. Hierop word vervolgens gelet.

\subsubsection{Versef teen instifusionalisme en formalisme}

In die geskiedenis van die Christendom het die kerk in alle kerklike tradisies in mindere of meerdere mate 'n sterk institusionele en formele struktuur aangeneem. Die kerk het as 'n formele organisasie met baie vorme, rites en tradisies langs ander organisasievorme te staan gekom. Die kerk het ontwikkel tot 'n institutêre gesagstruktuur wat as sodanig gefunksioneer het. Binne hierdie struktuur het alle aktiwiteit gesentreer rondom die besondere dienste. Hierdie formele struktuur het oor baie eeue ontwikkel en het wêreldwyd gevestig geraak (Dulles, 1987:35). Hoofsaaklik as gevolg van die Rooms-Katolieke kerkbeskouing, wat sê dat Christus in die biskoppe teenwoordig is, het die kerk as formele institutêre gesagstruktuur later self 'n objek van die mens se aanbidding geword (Vatican Council II, 1982:472). Hierdie aanbidding het daarop uitgeloop dat dit vir mense gaan om die instandhouding van die kerk, sy institutêre gesag en sy rites en nie primêr om diens aan God nie.

Bosch (1991:217) beskrywe hierdie ontwikkeling en noem dit uit 'n missiologiese hoek: "The Ecclesiasticization of Salvation". Dulles (1987:35) noem die ekklesiologiese model "institusionalisme". Dwarsdeur die kerkgeskiedenis het daar van tyd tot tyd verset teen hierdie institusionalisme met sy formalistiese godsdienspraktyk ontwikkel. Tans word die institusionalisme in mindere of meerdere mate in alle kerklike tradisies gevind en die ontwikkeling van groot ekumeniese liggame het die tendens versterk (Vorster, 1991:471). Mense beleef die kerk as 'n plek waarheen hulle gaan om sekere godsdienstige rites af te handel. Die kerk is die doel van die mens se godsdienstige aktiwiteit (Dekker, 1971:48). Die institusionalisme het dus gelei tot 'n bepaalde kerkmodel wat 'n instituutmodel genoem kan word. Hierdie benaming wys op 'n bedienings- 
patroon waarin alle aktiwiteit sentreer in die besondere dienste en waarin die diens van die gelowige onderwaardeer word en selfs tersyde gestel word.

Daar is tans weer wêreldwye verset teen hierdie institusionalisme met sy instituutmodel. Knox (1993:1) sê hieroor die volgende: "Institutional religion has become increasingly irrelevant to Westem culture despite its continuing importance in many areas and many groups of people".

Die GKSA gaan in die volgende dekades deeglik te doen kry met die verset, sowel in kerkbeskouing as in kerkbelewing, teen die instituutmodel met sy institusionalisme en formalisme. Op grond van insigte wat die Skrif en belydenis aangaande die kerk stel, sal hierdie verset effektief in die toekoms geakkommodeer moet word. Uit die kerkgeskiedenis kan in hierdie verband ook 'n belangrike les geleer word. Institusionalisme moet nie met nuwe institusionalistiese vorme vervang word nie. Latourette $(1953: 840,1079)$ toon aan hoe die Rooms-Katolieke Kerk met die Konsilie van Trente (1545-1563) en die Eerste Vatikaanse Konsilie (1869-1870) die destydse vorme van institusionalisme probeer bestry het met 'n hernude beklemtoning van 'n kerksentriese godsdiensbelewing. Hierdie poging het tot groter deformasie gelei.

Die antwoord moet eerder gesoek word in die beklemtoning van die kerk as middel en stimulus van godsdiensbelewing waarin die fokus verskuif van die makrostruktuur na die plaaslike gemeente, van die kerklike ampsgesag na amptelike dienslewering, van formele "kerkgesentreerde" aanbidding na spontane geloofsbelewing en roepingsvervulling deur gelowiges en van kerklike leiding na motivering deur die Woord. Die plaaslike gemeente sal weer tot sy reg moet kom en daar moet gewaak word teen sinodalisme waarin die vryheid van die plaaslike kerk ingeperk word

\subsubsection{Belewing in kleiner gemeenskappe}

In die nuwe postmoderne paradigma ontwikkel die mens nuwe behoeftes. Die belangrikste hiervan is ' $n$ besondere behoefte aan die aktiewe belewing van gemeenskap. Hierdie diepgevoelde behoefte moet gesien word as die mens se reaksie op die individualisme van die moderniteit. Die moderniteit, met sy beklemtoning van die rede en die rasionele benadering tot die werklikheid het die mens gedehumaniseer. Dehumanisering beteken dat die mens vanweë sy manipulasie deur die wetenskap en tegniek geestelik losgemaak is van sy omgewing en sy medemens soos Marcuse (1971:10) in sy reeds genoemde werk aangetoon het

Die kultuur van die moderniteit waaraan die wêreld vir twee eeue onderhewig was, en in 'n mate steeds is, het op hierdie wyse die vraagstuk van vereensaming geskep. Stott (1992:232) sê dat die moderne tegnokratiese samelewing die normale gemeenskap tussen mense vernietig het. Die mens het in 'n tyd van 
sosiale disintegrasie geleef waarin dit toenemend moeilik gevind is om met mekaar verhoudinge op te bou. Daarom soek die postmoderne mens juis dit wat hom, as gevolg van die moderne samelewing ontwyk, naamlik liefde.

Die eise van die Bybel en die eise van die tyd maak dit dus vir die kerk noodsaaklik om weer te besin oor hoe die gemeenskap van die gelowiges so ingeklee kan word dat die koinonia vandag en in die toekoms aan sowel die beginsel as die praktyk kan beantwoord (Edwards, 1987:444). Wuthnow (1993:32) maak die volgende veelseggende stelling: "The church of the twenty-first century, like that of previous centuries, will probably remain vibrant as long as it can provide people with a strong sense of community".

Edgar (1995:375) gaan ten opsigte van dieselfde saak selfs so ver as om te pleit vir 'n "post-kerklike teologie" waarin die klem verskuif word van die kerk as 'n struktuur na die kerk as gemeenskapsbelewing. Ook in hierdie verband word die tradisionele instituutmodel nie beskou as doeltreffend in die beantwoording van die mens se soeke na gemeenskap nie.

'n Aanduiding dat so 'n verskuiwing weg van die instituutmodel reeds besig is om plaas te vind, blyk uit die groei van selgroepe waarin gelowiges buite die verband van die geinstitueerde kerk allerlei vorme van geloofsgemeenskap met mekaar beoefen (Gibbs, 1992:155; Burger, 1995:91). Selgroepe buite die kerk is egter kerkafbrekend en kan nie as 'n alternatiewe wyse van gemeenskapsbelewing aanvaar word nie. 'n Positiewe ontwikkeling is egter die gebruik van kleingroepe binne die gemeente ten einde die gemeenskapsbelewing binne die gemeente te bevorder. Op die nut hiervan is reeds gewys deur Neighbour (1990:194), Beckham (1995:30) en in Gereformeerde kringe deur Oostenbrink (1996:127) en Vorster (1998:26). Vanuit gereformeerde oogpunt sal aan die saak aandag gegee moet word op so 'n wyse dat die beginsels vir bediening konkreet gestalte kry in nuwe bedieningsmodelle waarin die soeke na gemeenskap betrek word (vgl. Brueggeman, 1991:128). In dié proses sal nie net gekyk moet word na die beginsels wat ter sprake is nie, maar ook - en veral - na die aspekte in die omgewing van die hedendaagse gemeente wat, as gevolg van die teenswoordige paradigmaverskuiwing, egte gemeenskapsbelewing bemoeilik.

\subsubsection{Die beweging lerug na eenvoud}

Die postmoderniteit reageer teen die absolutisme en die heerskappy van superstrukture in die samelewing. Daar is 'n neiging terug na die eenvoud van die premoderniteit. Eenvoudige waardes word weer belangrik en menslikheid word belig teenoor die dehumanisering van die moderniteit. Hierdie nuwe lewenshouding het besondere implikasies vir die kerk. Daar ontwikkel in die kerke ook 'n verset teen ingewikkelde stelsels, moeilik verstaanbare dogmas, 
"koue" eredienste, rigiditeit, onpersoonlikheid, betekenislose tradisies en vormgodsdiens.

Hierdie neiging terug na eenvoud moet nie in alle opsigte negatief bejeën word nie. Die lewe van die eerste gemeentes was immers eenvoudig. Die gelowiges het byeengekom en in eenvoudige byeenkomste die Here gedien (Walker, 1992:23). Die Reformasie was ook 'n beweging terug na die eenvoud van die vroeg-Christelike kerke. So 'n beweging gaan vir die kerke in die volgende dekades uiters belangrik wees. Die plaaslike gemeente sal meer persoonlik, intiem, liefdevol en diensgerig moet funksioneer. Prediking en veral leerstellige prediking sal in eenvoud gekontekstualiseer moet word. Die ontwikkelende behoefte aan belewing en deelname sal geakkommodeer moet word. Maar juis hiervoor is die gereformeerde Ekklesiologie met sy klem op die plaaslike kerk en die amp van die gelowige by uitnemenheid toegerus. Hierdie beginsels, wat onder invloed van die moderniteit met sy sentralisering van gesag en dehumanisering grootliks in onbruik geraak het, sal in die proses van reformasie weer gepositiveer moet word.

\section{3 'n Nuwe waardesisteem}

Soos reeds aangetoon is, is relatiwisme die wagwoord in die waardesisteem van die postmodermiteit. Daar bestaan geen absolute en "tydlose" waarhede nie. Daar is ook nie ware en valse godsdienste nie. Godsdienste is gelykwaardig en die kerk is naas ander godsdiensgroepe alleen 'n moral opinionmaker. Die uniekheid van die Skrif word bevraagteken en die missionêre roeping van die kerk en die gelowige word as geestelike paternalisme beskou en as aktiwiteite wat nie tuishoort in die nuwe godsdiensvriendelike en verdraagsame klimaat nie.

Die nuwe beklemtoning van godsdienvryheid moet waardeer en bevorder word, maar die Christelike geloof kan nooit uitgaan van relatiewe waarhede en tydsbepaalde beginsels nie. In hierdie opsig gaan daar 'n intense konflik ontwikkel tussen die gereformeerde teologie en die waarheidsbeskouing van die dekades na 2000. Die kerk gaan al hoe meer te doen kry met gelowiges wat Skrifwaarhede en veral die belydenisskrifte gaan bevraagteken, nie omdat hulle worstel met die kernsake van die geloof nie, maar omdat hulle geprogrammeer word deur die denkmanier van die tyd wat deur die media en die gemeenskap waarin hulle leef aan hulle opgedis word. In 'n sekere sin word die postmoderne mens ook reeds "geleef" deur die gees van die tyd.

Binne hierdie raamwerk sal die kerk hom in besonder daarop moet toespits om beginseldenke te bevorder. Konkreet gestel, beteken dit dat die leerstellige prediking en kategetiese onderrig baie aandag sal moet kry en dat die prediking ook oortuigende leiding sal moet gee ten opsigte van etiese beginsels. Hiervoor is daar egter twee pertinente voorwaardes: eerstens moet die teologiese voorveronderstellings waarmee gewerk word deurlopend aan ondersoek onderwerp 
word. Hierdie proses is immers deel van semper reformanda. Die voortdurende herevaluering van die voorveronderstellings moet plaasvind deur middel van gesprek tussen gelowiges uit die verskillende denkrigtings wat daar in die gereformeerde tradisie bestaan. Onkritiese handhawing van eie voorveronderstellings lei tot 'n fundamentalistiese lewens- en wêreldbeskouing, kerkbeskouing en Skrifberoep.

Tweedens moet daar in aansluiting by bogenoemde 'n duidelik onderskeid gemaak word tussen egte Skrifbeginsels en tradisies wat oor die jare in die kerklike lewe die status van 'n beginsel gekry het. Die moderniteit het groot "dogmatiese" en etiese konstellasies op teologiese aannames gebou. 'n Rasionalistiese teologie het die Bybel verdwerg en die gereformeerde kerke het hieronder swaar gebuk gegaan. Gelowiges is gebind aan standpunte, etiese kodes en liturgiese praktyke waarin hulle die Skrif self nie meer kon sien nie. In die opbou van 'n waardesisteem vir die nuwe samelewing wat ontwikkel, moet die altyd geldende Skrifbeginsel opnuut ontgin word uit die verpakking van die moderniteit.

Soos reeds gesê is, is die spanning tussen tradisie en vernuwing tans baie gekonsentreerd en lei dit tot groot konflik in die kerke. Die vraag is dikwels: wat is beginsel en wat is tradisie? Die antwoord is nie eenvoudig nie en kan alleen uitgemaak word deur intensiewe gesprek op kerklike vergaderings en op ekumeniese vlak. Die kerke gaan gedwing word om deeglik voorraad op te neem van die beginsels waarom dit gaan in teologie en kerkwees. Hierdie proses is moeilik en konflikwekkend. Daarom moet moet dit met erns, liefde en wysheid gepaard gaan. Meerdere vergaderings moet seker maak dat hulle werklik op beginselsake konsentreer en moet nie die gewetens van gelowiges bind met tradisies op grond van kerklike of sinodale gesag nie. Dieselfde geld vir die prediking. 'n Oop kerklike debat oor die beginsels van die Christelike geloof en die kontekstualisering daarvan gaan in die volgende dekades noodsaaklik wees. Op hierdie wyse moet die gelowige opgeskerp word in beginseldenke ten einde die aanslag van leerstellige en etiese relatiwisme te deurstaan. In hierdie verband is die woorde van Aland (1986:497) aan die einde van sy boek belangwekkend:

Nothing but the way back to the whole message of the Bible - not merely as a doctrinal statement, but also as a reality that is experienced - can fully liberate the powers of Christianity so that it can renew itself, renew humankind, renew the world, and fulfil the commission which it has been given by the Lord.

\subsection{Spiritualiteit}

'n Verdere belangrik ontluikende megatendens is die hernude belangstelling van die postmoderne mens in die metafisiese. Hy wil agter die horisonne van die 
menslike rede inkyk en het 'n nuwe waardering vir God. In die moderniteit het die mens gevra of God bestaan; rasionele godsbewyse het die teologiese debat oorheers. In die ontluikende posmoderniteit vra die mens na 'n verhouding met God. Begrippe soos geloof, meditasie, afhanklikheid en geestelike verryking is aan die orde van die dag. Hierdie megatendens doen hom ook voor in die Christelike kerk. Teenoor die harde rasionalisme van die moderniteit het die mens vandag 'n groeiende behoefte aan die ervaring van 'n verhouding met God. Hy staan oop vir godsdiens. Hierdie verskynsel word gedefinieer as spiritualiteit (Houston, 1991:179). Talle boeke sien tans oor hierdie onderwerp die lig en daar word ook aandag gegee aan 'n gereformeerde spiritualiteit (Jonker, 1989:288, Snyman, 1997:375). Hierdie neiging hang saam met die beweging terug na eenvoud.

Die ervaring en belewing van 'n band met God was nog altyd 'n kernmoment in die gereformeerde teologie. Ou begrippe soos heiligmaking, vroomheid en godsvrug dui daarop. Die konsep van ervaring het egter onder die invloed van die moderniteit met sy beklemtoning van verstaan op die agtergrond verdwyn. Hierdie aspekte van geloofsaktiwiteit word tans weer deur gelowiges hoog geag. In 'n omgewing van baie vorme van spiritualiteit, gevoelsgodsdiens en piëtisme sal die kerke weer die eg gereformeerde vroomheid na die voorgrond moet bring. Oostenbrink en Lotter (1998:15) dui 'n weg aan waarop hierdie saak op 'n spontane wyse in die gemeente aandag kan kry. Daar kan ook ander weë uitgewerk word. Die belangrike is egter dat die kerke hierdie ontluikende megatendens ook sal moet hanteer om weer 'n gesonde gereformeerde spiritualiteit daar te stel. Hierdie soeke na spiritualiteit skep ook 'n besondere geleentheid vir 'n evangeliserende gesprek met nie-Christene (De Klerk, 1998:36)

\section{Slot}

Hoewel die wese en roeping van die kerk deur die eeue prinsipieel dieselfde bly, kan verskillende kontekste verskillende aksente vereis. Benewens die basiese roepingsvervulling in die volgende dekades sal bogenoemde megatendense die aksente vereis wat genoem is. Kontekstualisering is noodsaaklik vir die effektiwiteit van die kerk en vir die GKSA sal kontekstualisering in die groeiende postmoderne konteks die prioriteit van die bediening in die dekades na 2000 moet wees. Dat dit moontlik is, word histories bewys uit die feit dat die gereformeerde belydenis en kerkbegrip die konflik van die makroparadima van premoderniteit na moderniteit oorleef het asook verskeie meso- en mikroverskuiwings in verskeie historiese situasies en kontekste (Aland, 1986:481). Die gereformeerde teologie het reeds getoon dat dit 'n inwendige dinamiek het wat die storms van die tyd kan oorleef. Met inagneming van die spesifieke gerigthede wat nou vereis word, sal dit ook die huidige verskuiwing oorleef. 
In so 'n paradigmaverskuiwing is die klimaat vir reformasie besonder gunstig. Die kerk word gedwing om sy erfenis weer na waarde te skat. Kerklike introspeksie is onvermydelik, maar 'n herwaardering van die vaste beginsels bied nuwe dryfkrag en motivering. Daar kan dus 'n opwindende toekoms vir die GKSA voorlê.

\section{Bibliografie}

ADAM, A.K.M. 1995. What is postmodern Biblical criticism. Mineapolis : Fortress ALAND, K. 1986. A history of Christianity. Vol 2 Philadelphia : Fortress Press ALTIZER, T.J.J. 1966. Theology and the death of God. (In Altizer, T.J.J. \& Hamilton, W Radical theology and the death of God New York/Kansas City : Bobbs Merrill.)

ANDERSON, L. 1990. Dying for change. An arresting look at the new realities confronting churches and para-church ministries. Minneapolis : Bethany House Publishers.

BANNING, W. 1961. De "moderne wereld" (van Descartes tot Kant). (In Banning, W, e.a. Europese Geest. Zeist, De Haan/Amhem, Van Loghym Slaterus/Antwerpen, N.V Standaard Boekhandel. p. 227-268.)

BARKER, S. 1996 Signs of change. Premodern-modern-postmodern. Albany : State University of New York Press

BECKHAM, W.A. 1995. The second reformation: reshaping the church for the twenty-first century. Houston : Touch Publications.

BOAS, G. 1957. Dominant themes of modern philosophy New York : Ronald Press

BOSCH, D.J. 1991. Transforming mission: Paradigm shifts in theology of mission. New York : Mary-Knoll.

BRUEGGEMAN, W 1991. Rethinking church models through Scripture Theology Today, 2:128-138, Jul.

BURGER, C. 1995. Gemeentes in transito. Vernuwingsgeleenthede in 'n oorgangstyd Kaapstad : Lux Verbi.

CAIRNS, E.E. 1982. Christianity through the centuries A history of the Christian church. Grand Rapids : Zondervan

COOK, E.D. 1988. Logical positivism. (In Ferguson, S.P., ed New dictionary of theology. Leicester : Inter-Varsity Press p 394-395.)

COX, H 1966 Beyond Bonhoeffer. (In Callahan, D, e.a. The secular city debate. London Coldier/Macmillan/New York : Macmillan.)

COX, H. 1967. De stad van de mens, het levenspatroon van de moderne wereld in theologisch perspectief. Utrecht : Ambo Boeken

DE KLERK, W. 1998. Die vreemde God en sy mense Kaapstad : Human en Rousseau.

DEKKER, G. 1971. Wat is er met de Kerk aan de hand? Over de positie en funksie van de kerk in de huidige samenleving. Kampen : Kok

DU TOIT, D A 1988 Die mens en sy regte Kaapstad : Zebra Publikasies

DULLES, A. 1987. Models of the church. New York : Double Day

EUBEN, RL. 1997. Premodern, antimodern or postmodern? Islamic and Western critiques of modernity. The Review of Politics, 59(2):429-459, June

EDGAR, W. 1995. No news is good news: modernity, the postmodern and apologetics. The Westminster Technological Journal, 57(2):359-383

EDWARDS, D.L 1987. The futures of Christianity London: Hodder \& Stoughton

FIERRO, A. 1977. The militant Gospel. An analysis of contemporary political theologies London : SCM Press

GES $k y k$ GEREFORMEERDE EKUMENIESE SINODE

GEREFORMEERDE EKUMENIESE SINODE. 1983 RES testimony on human rights Michigan : Grand Rapids RES 
GIBBS, E. 1992. I believe in church growth. London : Hodder \& Stoughton.

GIBBS, E. 1993. Winning them back. Tackling the problem of nominal Christianity Kent Monarch Publishers

GUTIERREZ, G. 1974. A spirituality of liberation. (In Kee, A. A reader in political theology London : SCM Press.)

HAMILTON, W. 1966. The death of God theologies today. (In Altizer, T.J J. \& Hamilton, W., eds. Radical theology and the death of God. New York/Kansas City : Bobbs Merrill.)

HEELAS, P 1993. The New Age in cultural context: the premodem, the modem and the postmodern Religion, 23:103-116.

HENDRIKS, H.J. 1996. Kerkspieël IV en die NGK statistiek in die wyer perspektief van die Suid-Afrikaanse Bevolkingsensusse 1911-1991. Nederduits Gereformeerde Teologiese Tydskrif, 37(1): 138-145.

HERHOLDT, M.D. 1998. Postmodern theology. (In Maimela, S \& Konig, A Initiation into theology. The rich variety of theology and hermeneutics. Pretoria : Van Schaik p. 215239)

HŌFFE, O. 1982. Die Menschenrecht in der Kirche. (In Hertz, A., e.a Handbuch der Christlichen Ethik. Freiburg : Guterslöh Verlagshaus Gerd Mohn p. 236-255)

HOUSTON, JM. 1991. Spiritual life today: an appropriate spirituality for a post-modern world (In Eden, M. \& Wells, D.F., eds. The Gospel in the modern world. Leicester Inter-Varsity Press. p. 179-187.)

JONKER, W.D. 1989 Die eie aard van gereformeerde spiritualiteit. Nederduits Gereformeerde Teologiese Tydskrif, 30:288-299

JORDAAN, W J 1994 Menseregte: 'n sielkundige perspektief. (In Vos, C.J.A \& Muller, J C. Menswaardig. Halfway House : Orion p. 33-55.)

KIK, A 1982. Geloof in menschenrechten. Kampen : Kok.

KLAAS, A C. 1996 In search of the unsearched. New York : The Alban Institute.

KNOX, C. 1993. Changing Christian paradigms and their implications for modern thought. New York : Brill

KÖNIG, A 1993. Menslike mense. Gelowig nagedink Deel 5. Oor die mens en die sonde in die praktyk Halfway House : Orion

KUHN, T.S. 1970 The structure of scientific revolutions. Chicago. The University of Chicago Press

KUNG, H 1995. Christianity. Its essence and history. London : SCM Press.

LAMBERTH, DC. 1997 Intimations of the finite: thinking pragmatically at the end of modernity Harvard Theological Review, 90(2):205-223.

LATEGAN, B C 1988. Why so few converts to new paradigms in theology? (In Mouton, J., Van Aarde, A.G \& Vorster, W.S. Paradigms and progress in theology. Pretoria HSRC.)

LATOURETTE, K.S. 1953. A history of Christianity London, Evanston, New York : Harper \& Row Publishers

LOCHMAN, J.M 1976. Um eine christliche Perspektive fur Menschenrechte (In Lochman, J.M. \& Moltmann, J. Gottes Recht und Menschenrechte. Bielefeld : Klemme und Bleimund. p. 7-19.)

MARCUSE, H 1968. Eros en cultuur. Utrecht : Bijleveld.

MARCUSE, H. 1971 De eendimensionele mens, studies over de ideologie van de hoogindustrièle samenleving. Bussem : Paul Brand

McGRATH, AE 1992 Bridge-building Effective Christian apologetics Leicester : InterVarsity Press

MEAD, L.B 1993 The once and the future church Reinventing the congregation for a new mission frontier. New York: The Alban Institute 
MOLTMANN, J. 1994. Christianity in the third millenium. Theology Today, 51(1):75-89

NEIGHBOUR, R.W. 1990. Where do we go from here? A guidebook for the cell group church. Houston: Touch Publication.

OOSTENBRINK, J.W 1996. Korporatiewe spiritualiteit en kleingroepleierskap. Potchefstroom : PU vir CHO. (Ph.D.-proefskrif.)

OOSTENBRINK, J.W \& LOTTER, G.A. 1998. Kleingroepe ter fasilitering van spiritualiteit in die kerk. In die Skriflig, 32(1):1-18, Maart

OZMENT, S. 1995. Premodern advice for the postmodern young The Public Interest, 119:54-67, March.

PEPERZAK, A T. 1997. Philosophia Faith and Philosophy, 14(3):321-333.

PIETERSE, H.J.C. 1992a. Die diskussie oor sommige ondersoekmetodes binne die praktiese teologie Theologia Evangelica, 25(3):16-24, September

PIETERSE, H.J.C. 1992b. Woord en werklikheid in die moderne praktiese teologie. In die Skriflig, 26(3):325-335, September

POLAK, F.L. 1958 De tnekomst is verleden tijd, 'n cultuur-futuristische verkenning Zeist De Haan

ROBINSON, J.A.T. 1964 Honest to God. London : SCM Press

ROSZAK, T. 1969. The making of a counter culture reflection on the technocratic society and its youthful opposition. New York: Doubleday Company.

SANKS, T.H. 1974. Authority in the church. A study in changing paradigms. Montana Scholar Press.

SHAULL, R. 1969. Uitdaging aan kerk en maatschappij. Baarn : Het Wêreldvenster.

SMITH, D. 1993 . The premodern and the postmodern: some parallels, with special reference to Hinduism. Religion, $23: 157-165$

SNYMAN, S.D. 1987. Spiritualiteit - 'n perspektief uit die Ou Testament. In die Skriflig, 31(4):375-387, Desember.

SOLLE, D. 1965. Plaatsbekleding. Amsterdam : Ten Have

SOLLE, D. 1970 Fantasie en gehoorsaamheid, toekomst en christelijke etiek Baarn : Bosch \& Keuning

SOLLE, D 1972. Politieke theologie, discussie met Rudolf Bultmann Baarn : Bosch \& Keuning

SOLLE, D. \& STEFFENSKY, F, 1969. Politiek avondgebed 2 dele Baarn: Bosch \& Keuning

STOTT, JR W. 1992. The contemporary Christian: an urgent plea for double listening Leicester : Inter-Varsity Press.

TOFFLER, A. 1971. Future shock London : Pan Books.

TOFFLER, A. 1980. The third wave. London : Welham Collins

TOFFLER, A. 1990. Powershift: knowledge, wealth and violence at the edge of the 21 st Century. New York : Bantam Books.

TRACEY, D. 1994. Theology and the many faces of postmodernity Theology Today, $51(1): 104-114$

VAN BUREN, P M. 1968. Theological explorations London : SCM Press.

VAN DER VYVER, J.D. 1974 Menseregte Potchefstroom : Instituut vir die bevordering van Calvinisme

VAN WYK, J.H 1991. Moraliteit en verantwoordelikheid: opstelle oor politieke etiek Potchefstroom : PU vir CHO

VATICAN COUNCIL II. 1982. Dogmatic constitution on the church (In Leith, J H, ed Creeds of the churches A reader in Christian doctrine from the Bible to the present Atlanta John Knox Press )

VILLA-VICENCIO, C. 1992. A theology of reconstruction. Cambridge : University Press

VORSTER, J.M. 1981. Die kerk en die kleurvraagstuk vandag Johannesburg : De Jongh 
VORSTER, J.M. 1988. Die toerustingstaak van die Gereformeerde predikant: 'n praktiese bedieningsmodel In die Skriflig, 32(1):19-35, Maart.

VORSTER, J M. 1991. Buite-kerklikheid en makro-kerklikheid in die moderne Ekklesiologie. In die Skriflig, 25(4):471-483, Desember.

VORSTER, JM 1996 Is die kerk funksioneel? Gedagtes oor Gereformeerde kerkvernuwing in 'n post-moderne konteks Potchefstroom : Potchefstroomse Teologiese Publikasies.

VORSTER, J.M. 1998. Periodisation in Church History. Studia Historiae Ecclesiasticae, 24(1): 208-225.

VORSTER, W.S 1988 Towards a post-critical paradigm: progress in New Testament scholarship. (In Mouton, J., ed Paradigms and progress in theology Pretoria : HSRC)

WALKER, W 1992. A history of the Christian church. Edinburgh : Clark.

WINGREN, G 1978. Mensenrechten - een theologische analyse (In Ter Vrugt-Lenz \& Van der Voort, I.N.A. Mensenrechten in oost en west. Leusden : Algemeen Diakonaal Bureau van de Gereformeerde Kerken in Nederland )

WOODS, C J. 1996. Congregational megatrends New York: The Alban Institute

WUTHNOW, R. 1993. Christianity in the twenty-first century. Reflections on the challenges ahead. Oxford : Oxford University Press.

ZYLSTRA, C 1992. Church growth in a pluralist society. Pro Rege, 21(1):9-17, Sept 
